\title{
Metabolic myocardial disorders in children with bronchial asthma
}

\author{
0. V. Herasymova, T. L. Protsiuk, L. O. Protsiuk, O. B. Dudarenko, O. V. Kuleshov
}

National Pirogov Memorial Medical University, Vinnytsia, Ukraine

Key words:

bronchial asthma, child, biomarkers, cardiovascular system.

\section{Pathologia} 2018; 15 (3), 296-301 Dol:

10.14739/2310-1237 2018.3.151707

E-mail:

rossata@ukr.net
Objective. To study specific features of potassium metabolism and myocardial damage markers in the children with bronchial asthma, depending on the level of BA control.

Materials and methods. Comprehensive examination was carried out in 189 children with persistent BA aged 6-17 years: group 1 consisted of 124 with uncontrolled course of the disease, group $2-30$ patients with partially controlled BA and 35 patients with controlled BA. The comparison group consisted of 30 patients with controlled asthma without changes from the cardiovascular system. The unified flame photometry method with fluid analyzer FFA-1 was used to determine the erythrocyte potassium level. Total creatine phosphokinase level was estimated by UV-test. Creatine phosphokinase-MB level was determined by M-subunit immunoinhibition. Total lactic dehydrogenase-1 level was calculated by modified colorimetric method using an assay kit for colorimetric determination of total LDH. Serum LDH1 level was estimated by UV-method with the kit for determination of isoenzyme LDH1 activity.

Results. In the children with UC BA serum $\mathrm{K}^{+}$and erythrocyte $\mathrm{K}^{+}$level was significantly lower compared to the children with PC BA, C BA, C BA with no changes in CVS and the control group. Total CPK and CPK-MB isoenzyme level in the children with UC BA, was significantly higher compared to those with PC BA, C BA, C BA without CVS changes and the control group. In the children with PC BA, total serum $C P K$ level was also significantly higher compared to $C B A(P=0.007), C B A$ without CVS $(P=0.0002)$ changes and the control group $(P=0.001)$.

Conclusion. Thus, the study demonstrated significant decrease of potassium level in blood serum and erythrocytes, twofold increase of total creatine phosphokinase and lactic dehydrogenase- 1 isoenzyme levels, threefold increase in creatine phosphokinase-MB isoenzyme level, and one and a half time increase of total lactic dehydrogenase in the children with uncontrolled course of bronchial asthma.
Киючові слова: бронхіальна астма, Аіти, серцевосудинна система, біомаркери.

Патологія. - 2018. T. 15, № 3(44). C. 296-301

\section{Метаболічні порушення в міокарді в дітей при бронхіальній астмі}

\section{О. В. Герасимова, Т. А. Процюк, ^. О. Процюк, О. Б. Аударенко, О. В. Кулешов}

Мета роботи - дослідити особливості обміну калію та маркерів ушкодження міокарда в дітей, які хворі на бронхіальну астму (БА) з різним рівнем контролю.

Матеріали та методи. Обстежили 189 дітей віком від 6 до 17 років, які хворі на БА, що персистує. Перша група - 124 дитини з неконтрольованим перебігом (НК) хвороби, друга - 30 пацієнтів із частково контрольованою (ЧК) і 35 пацієнтів із контрольованою БА. Група порівняння - 30 дітей із контрольованим (К) перебігом БА без змін із боку серцево-судинної системи (ССС). Контрольна група - 95 практично здорових дітей. Для визначення калію в еритроцитах застосовували уніфікований метод фотометрії полум'я за допомогою аналізатора рідини ПАЖ-1. Для визначення загальної креатинфосфрокінази (КФК) використовували кінетичний UV-тест. Для визначення креатинфосфрокінази-МВ (КФК-МВ) застосовували метод імуноінгібування M-субодиниць із наступним визначенням UV-кінетичним методом. Для встановлення загальної лактатдегідрогенази (ЛДГ) застосовували модифрікований колориметричний метод, використовуючи набір реактивів для колориметричного визначення загальної ЛДГ. Рівень лактатдегідрогенази-1 (ЛДГ $)$ ) у сироватці крові встановили кінетичним УФ методом.

Результати. Протягом дослідження встановили, що в дітей із НК БА рівень $\mathrm{K}^{+}$у сироватці та еритроцитах крові був вірогідно нижчим порівняно з дітьми з ЧК БА, К БА, К БА без змін у ССС і контрольної групи. У дітей із ЧК БА рівень $\mathrm{K}^{+}$у сироватці крові був вірогідно знижений порівняно з дітьми із К БА, групою порівняння та контрольною групою. Рівень загальної КФК та ізоферменту КФК-МВ фракції в дітей із НК БА виявився вірогідно вищим порівняно $з$ дітьми з ЧК БА, К БА, К БА без змін у ССС та контрольної групи. У дітей із ЧК БА рівень загальної КФК у сироватці крові також був вірогідно підвищений порівняно з К БА, К БА без змін у ССС і дітьми контрольної групи.

Висновки. Результати дослідження вказують на вірогідне зниження рівня калію в сироватці крові, еритроцитах і збільшення вдвічі рівня загальної креатинфосфокінази та ізоферменту лактатдегідрогенази-1, втричі - ізоферменту креатинфосфокінази-МВ фракції, в 1,5 раза - загальної лактатдегідрогенази в дітей із неконтрольованим перебігом бронхіальної астми.
Ключевые слова: бронхиальная астма, Аети, сердечно-сосуАистая система, биомаркеры.

Патология. - 2018. T. 15, № 3(44). C. 296-301

\section{Метаболические нарушения в миокарде у детей с бронхиальной астмой}

\section{Е. В. Герасимова, Т. А. Процюк, А. А. Процюк, О. Б. Аударенко, А. В. Кулешов}

Цель работы - изучить особенности обмена калия и маркеров повреждения миокарда у детей, больных бронхиальной астмой (БА) с разным уровнем контроля.

Материалы и методы. Обследовали 189 детей в возрасте от 6 до 17 лет, больных персистирующей БА. Первую группу составили 124 ребенка с неконтролируемым (НК) течением болезни, вторую - 30 пациентов с частично контролируемой (ЧК) и 35 пациентов с контролируемой (К) БА. В группу сравнения вошли 30 детей с контролированным течением БА 
без изменений со стороны сердечно-сосудистой системы (ССС). Группа контроля - 95 практически здоровых детей. Для определения калия в эритроцитах применяли унифицированный метод фотометрии с помощью анализатора жидкости ПАЖ-1. Для определения общей креатинфосфоокиназы (КФК) использовали кинетический UV-тест. Для определения креатинфоосфокиназы -MВ (КФК-МВ) применяли метод иммуноингибирования М-субъединиц с последующим определением UV-кинетическим методом. Для определения общей лактатдегидрогеназы (ЛДГ) применяли модифицированный колориметрический метод с использованием набора реактивов для колориметрического определения общей ЛДГ. Уровень лактатдегидрогеназы-1 (ЛДГ ) в сыворотке крови устанавливали кинетическим УФ методом.

Результаты. В ходе исследования установлено, что у детей с НК БА уровень $\mathrm{K}^{+}$в сыворотке и эритроцитах крови достоверно ниже по сравнению с детьми с ЧК БА, К БА, К БА без изменений в ССС и контрольной группой. У детей с ЧК БА уровень $\mathrm{K}^{+}$в сыворотке крови достоверно снижен по сравнению с детьми с К БА, группой сравнения и контрольной группой. Уровень общей КФК и изофермента КФК-МВ фракции, у детей с НК БА оказался достоверно выше по сравнению с детьми с ЧК БА, К БА, К БА без изменений в ССС и контрольной группе. У детей с ЧК БА уровень общей КФК в сыворотке крови также был достоверно повышен по сравнению с К БА, К БА без изменений в ССС и детьми контрольной группы.

Выводы. Результаты исследования указывают на достоверное снижение уровня калия в сыворотке крови, эритроцитах и увеличение вдвое уровня общей КФК и изофермента ЛДГ , втрое - изофермента КФК-МВ фракции, в 1,5 раза - общей лактатдегидрогеназы у детей с неконтролируемым течением бронхиальной астмы.

Bronchial asthma (BA), a chronic recurring disease, remains an urgent medical, social, economic problem of modern society and public health service [1]. This is determined by a number of factors including steady increased morbidity, early onset of the disease, late diagnostics, necessity in a long-term basic therapy and constant control of disease symptoms [2].

Severe choking fits, emphysema of the lungs, chronic hypoxia and hypoxemia, developing in BA, marked neurovegetative imbalance, steady rise of pulmonary artery pressure are accompanied by considerable disturbances of metabolic processes in the myocardium [3]. Deficiency of ATP in myocardium during hypoxia and hypoxemia results in various myocardial dysfunctions on the systemic, cellular, subcellular and molecular levels. These changes lead to inability of myocardial cells to maintain proper metabolism for their life activity and functioning [4]. For this reason, early diagnostics of myocardial metabolic disturbances are of great significance.

The earliest manifestation of significant metabolic and morphologic changes in the myocardium in moderate and severe BA is an increase of enzymes of creatine phosphokinase fraction (CPK-MB) and lactic dehydrogenase-1 (LDH1) in blood [5]. Levels of those enzymes are increased by $10-46 \%$ in $50 \%$ of children with moderate BA, while 30-52 \% increase of CPK-MB and $\mathrm{LDH} 1$ levels is noted in $70 \%$ of children with severe $B A$ [5]. An increased level of cardio-specific enzymes is observed two-three weeks before ECG shows the signs of repolarization and depolarization disturbances. This can serve as diagnostic and prognostic criteria of BA severity, as well as the evidence of the efficiency of drug therapy of underlying disease and cardiovascular disorders [6].

Dealing with the problem "bronchial asthma and the heart", the role of micro-element potassium $\left(\mathrm{K}^{+}\right)$ should be emphasized. Potassium is known to promote intensive water excretion - it facilitates the functioning of cardiovascular system (CVS) in case of its insufficiency, participates in formation of electric pulses in the heart, and myocardial contractility. Normal $\mathrm{K}^{+}$level prevents arrhythmias, improves oxygen supply of brain cells, decreases blood pressure, prevents fatigue, increases physical endurance. There are BA cases, when serum $\mathrm{K}^{+}$level is considerably decreased, primarily due to the inhaled beta-2 agonists. Their frequent use leads to penetration of potassium into the cells and, subsequently, to its decreased level in the blood by $0.5-1.0 \mathrm{mEq} / \mathrm{l}$. A number of studies demonstrated beta-2 agonists, short-acting in particular, to cause decreased serum potassium level $[7,8]$. It should be considered, that glucocorticoids can increase the urine excretion of potassium as well. Thus, unsystematic intake of beta- 2 agonists, unreasonable increase of glucocorticoid doses can trigger negative effects related to the disturbances of potassium metabolism.

\section{Objective}

To study specific features of potassium metabolism and myocardial damage markers in the children with bronchial asthma, depending on the level of BA control.

\section{Materials and methods}

Comprehensive examination was carried out in 189 children with persistent BA aged 6-17 years, treated at the in-patient pulmonology department of Vinnytsia Regional Clinical Hospital, and 95 apparently healthy children of the control group. The comparison group consisted of 30 patients with controlled asthma (BA) without changes from the cardiovascular system (CVS). The diagnosis was made according to the criteria presented in the "Protocol of diagnosis and treatment of bronchial asthma in children", approved by the Order of the Ministry of Health of Ukraine of October 8, 2013.The children were divided into groups according to BA control level, determined by asthma control test (ACT-test). Group 1 consisted of 124 patients $(65.61 \%)$ with uncontrolled course of the disease (UC BA), group $2-30$ patients (15.87 \%) with partially controlled BA (PC BA) and 35 patients (18.52\%) with controlled BA (C BA).

Inclusion criteria were the following: previously verified BA not less than for two years; age between 6 and 17 years inclusive; period of BA exacerbation; increase of FEV1 $>12 \%$ after salbutamol inhalation according to spirography data and/or PEFR variability of $>20 \%$ after peakflowmetry; presence of day symptoms not less than 2 episodes a week; those who had received basic therapy 
in SMART regime; ability of patients and their parents to realize the information in ACT-test and questionnaires on quality of life of children; ability to use inhaler and peak flow meter properly; informed consent of parents to cooperate with the investigator in the study.

Exclusion criteria were the following: FEV $1<60 \%$ of normal; intake of drugs not indicated in clinical protocol of BA treatment in children; continuous basic therapy with systemic glucocorticosteroids (GS) and antileukotrienes for a month or more before the enrollment; hypersensitivity and/or contraindications to components of the drugs included in treatment regimen.

The unified flame photometry method with fluid analyzer FFA-1 (Ukraine) was used to determine the erythrocyte potassium level. Total creatine phosphokinase (CPK) level was estimated by UV-test (NAC-activation) with CPK determination kit, and control serums SERODOS, produced by the firm "Human", Germany. According to this method, the norm of creatine phosphokinase in serum was: in girls 6-12 years old - $154 \mathrm{U} / \mathrm{l}, 12-17$ years - $123 \mathrm{U} /$; ; in boys 6-12 years - $247 \mathrm{U} / \mathrm{l}, 12-17$ years $-270 \mathrm{U} / \mathrm{l}$.

Creatine phosphokinase-MB (CPK-MB) level was determined by M-subunit immunoinhibition and UV-kinetic method with the kit for CPK-MB determination, and control serums with human CPK-MB (the firm "Human", Germany). According to this method, the norm of creatine phosphokinase-MB in blood serum was: $24 \mathrm{U} / \mathrm{l}$.

Total lactic dehydrogenase-1 (LDH1) level was calculated by modified colorimetric method using an assay kit for colorimetric determination of total LDH, and control serums SERODOS (the firm "Human", Germany). "Humalyzer 2000" device, produced by the firm "Human" (Germany), was used to determine CPK, CPK-MB and LDH levels. The norm of total LDH in blood serum was: in children 2-10 years - not more than $290 \mathrm{U} / \mathrm{l}$, over 12 years - not more than $250 \mathrm{U} / \mathrm{l}$.

Serum LDH1 level was estimated by UV-method with the kit for determination of isoenzyme LDH1 activity, produced by the firm "Filicit-Diagnostics" (Ukraine), with photoelectric photometer CPK-3-01 (Zagorsk Factory of Optical Mechanics, RF). According to this method, the LDH1 norm in serum was $72-182 \mathrm{U} /$.

Statistical data processing was done with Statistical package for Windows v. 8.0 (№AXXR910A374605FA) using parametric and nonparametric methods. The normal distribution was evaluated according to Shapiro-Wilk test. Digital information of all clinical investigations was processed by variance statistical method calculating the mean value $(\mathrm{M})$ and its error $(\mathrm{m})$. The significance of difference between two means was calculated by Student's t-test $(t)$, between two relative values - by Fisher angular transformation method (f). For all specific data, the median (Me), lower and upper quartiles [LQ 25-UQ 75] were established. Two unrelated groups were compared by Mann-Whitney U-test. Two related samples were compared by Wilcoxon T-test. All $P$ values of less than 0.05 were considered to indicate statistical significance. Correlation analysis with calculation of Spearman rank correlation ( $r$ ) was used to establish the relationship between the studied indices.

\section{Results}

In the children with $\mathrm{UC}$ BA serum $\mathrm{K}^{+}$level was found to be 3.2 [3.0-4.0] mmol/l, being significantly lower compared to the children with $\mathrm{PC} \mathrm{BA}-3.7$ [3.2-4.2] $\mathrm{mmol} / \mathrm{l}(\mathrm{P}<0.01)$, C BA - 4.2 [3.8-4.5] mmol/l $(P<0.001), C$ BA with no changes in CVS- 4.3 [3.8-4.7] $\mathrm{mmol} / \mathrm{l}(\mathrm{P}<0.001)$, and the control group - 4.4 [3.9-4.8] $\mathrm{mmol} / \mathrm{l}(\mathrm{P}<0.001)$. Besides, in the children with PC BA serum $\mathrm{K}^{+}$level was also significantly decreased compared to those with $\mathrm{C} B A$, the group of comparison and the control group $(P<0.01)$ (Fig. 1).

The analysis of erythrocyte $\mathrm{K}^{+}$level demonstrated it to be 68.0 [60.0-80.0] $\mathrm{mmol} / /$ in the children with UC BA, being significantly lower compared to the children with $P C$ BA - 80.0 [62.0-84.0] mmol/l, $(P<0.001), C$ BA - 82.0 [78.0-92.0] mmol/l $(P<0.001), C$ BA with no changes in CVS - 83.3 [79.0-92.0] mmol/I $(P<0.001)$, and the control group - 84.3 [80.0-93.0] $\mathrm{mmol} / \mathrm{l},(\mathrm{P}<0.001)$. No significant difference in erythrocyte $\mathrm{K}^{+}$level was found in the children with $\mathrm{PC} B A, C B A, C$ BA with no changes in CVS and the control group $(P>0.05)$.

The analysis of the ratio of $\mathrm{K}^{+}$level in blood serum to that in erythrocytes showed that $32.3 \pm 4.2 \%$ of children with UC BA and $13.3 \pm 6.2 \%$ of those with PC BA $(P<0.05)$ had hypokalemia. Hypokalihistia was found in $18.5 \pm 3.5 \%$ of the children with UC BAand in $10.0 \pm 5.5 \%$ of those with PC BA $(P>0.05)$. Simultaneous decrease of $\mathrm{K}^{+}$level in blood serum and erythrocytes was observed in $17.7 \pm 3.4 \%$ of children with UC BA and in $6.7 \pm 4.6 \%$ of those with $\mathrm{PC} B A(P>0.05)$. Conversely, hypokalemia, hypokalihistia and simultaneous decrease of $\mathrm{K}^{+}$level in blood serum and erythrocytes were not revealed in the children with C BA, the group of comparison and the control group.

As the decreased $\mathrm{K}^{+}$level in blood serum and erythrocytes was found to be more evident in the children with UC BA, we set the goal to establish the most likely causes of its decrease in that category of children.

Positive moderate correlation relationship was found between the frequency of short-acting beta-2 agonist intake and hypokalemia in the children with UC BA $(r=0.45$, $P<0.001)$. In those children positive moderate correlation relationship between the duration of the disease and erythrocyte $\mathrm{K}^{+}$level was found as well $(r=0.40, P<0.001)$.

In the children with UC BA and simultaneous decrease of $\mathrm{K}^{+}$level in blood serum and erythrocytes the following correlation relationships were found: positive moderate correlation relationship between $\mathrm{K}^{+}$value and the frequency of short-acting beta- 2 agonist intake $(r=0.42$, $P<0.001)$, as well as positive moderate correlation relationship between the duration of the disease and simultaneous decrease of $\mathrm{K}^{+}$level in blood serum and erythrocytes $(r=0.49, P<0.001)$. In those category of children negative moderate correlation relationship between the compliance to basic therapy and simultaneous hypokalemia and hypokalihistia was found as well $(r=-0.40, P<0.05)$.

Among the children with UC BA and hypokalemia, $42.7 \pm 4.4 \%$ had $\mathrm{T}$ wave amplitude decrease, $7.3 \pm 2.2 \%$ - ST segment depression, and $20.2 \pm 3.6 \%$ simultaneous T wave amplitude decrease and ST segment depression. Among those with hypokalihistia and uncontrolled BA course, $47.6 \pm 4.5 \%$ had prolonged QT 
interval, $16.9 \pm 3.4 \%-$ ST segment depression, and $34.7 \pm 4.3 \%$ - simultaneous T wave amplitude decrease and ST segment depression. In the group of children with UC BA and simultaneous decrease of $\mathrm{K}^{+}$level in blood serum and erythrocytes, $77.4 \pm 3.7 \%$ had combined ECG changes: prolonged QT interval, T wave amplitude decrease and ST segment depression. Prolonged QT interval was found in $22.5 \pm 3.7 \%$ of children.

The children with UC BA, hypokalihistia, and combined hypokalemia and hypokalihistia had prolonged QT interval more often, indicating an increased risk of fatal arrhythmias and sudden death syndrome.

The results of study of myocardial damage markers, depending on various levels of BA control. Total CPK level was 295.1 [290.1-302.2] U/I in the children with UC $\mathrm{BA}$, being significantly higher compared to those with $\mathrm{PC}$ $\mathrm{BA}$ - 225.0 [180.0-289.3] U/I (P < 0.01), C BA - 155.1 [143.1-175.0] U/I $(P<0.001), C$ BA without CVS changes - 153.3 [140.2-173.0] U/l $(P<0.001)$ and the control group - 152 [140.2-172.0] U/l $(P<0.001)$. In the children with $\mathrm{PC} B A$, total serum $\mathrm{CPK}$ level was also significantly higher compared to $C B A(P<0.01), C B A$ without $C V S$ $(P<0.01)$ changes and the control group $(P<0.01)$. There was no significant difference between that index in the children with $C B A, C B A$ without CVS changes and the control group $(P>0.05)$ (Fig. 2).

Having analyzed CPK-MB isoenzyme level in all studied groups, a similar tendency was found: its significant increase in the children with UC BA-61.2 [46.0-69.5] U/I compared to the children with PC BA - 37.5 [25.0-52.2] $\mathrm{U} / \mathrm{I}(\mathrm{P}<0.01), \mathrm{C} B A-22.5$ [19.2-26.8] U/I $(\mathrm{P}<0,001)$, C BA without CVS changes - 20.0 [18.4-24.4] U/I $(P<0.001)$ and the control group - 19.6 [16.2-22.3] U/I $(P<0.001)$. CPK-MB level in the children with PC BA was also significantly increased compared to those with C BA, C BA without CVS changes and the control group $(P<0.01)$ (Fig. 2).

Total serum LDH level was found to be significantly increased in the children with UC BA - 406.2 [260.2-496.2] U/l compared to those with PC BA - 270.2 [246.0-316.2] $\mathrm{U} / \mathrm{I}(\mathrm{P}<0.01), \mathrm{CBA}-262.3$ [242.1-306.2] U/I $(\mathrm{P}<0.001)$, C BA without CVS changes - 261.1 [241.1-302.3] U/I $(P<0.001)$ and the control group - 260.0 [240.2-293.0]

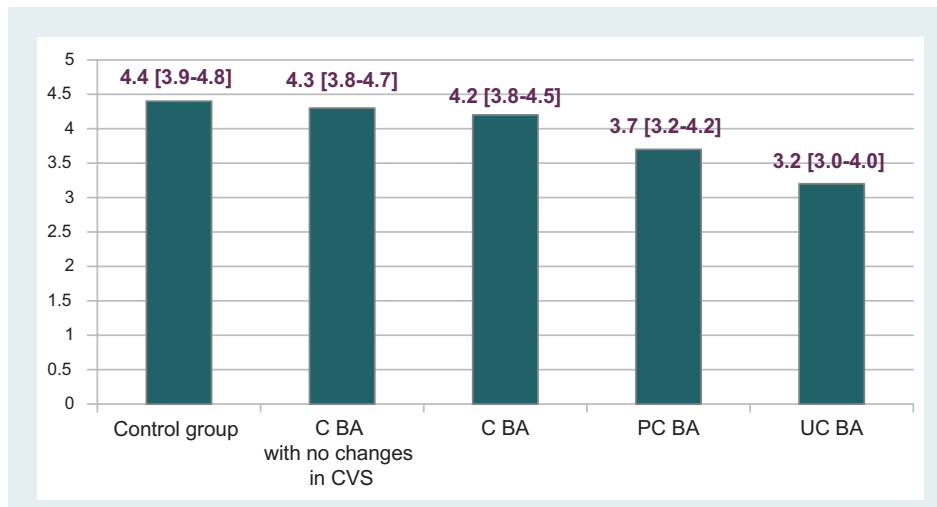

Fig. 1. The level of serum potassium in children at different levels of bronchial asthma control ( $\mathrm{mmol} / \mathrm{l})$.

$U / I(P<0.001)$. No other difference in that index within the comparison groups was found $(P>0.05)$. Having calculated isoenzyme LDH level as percentage of total serum LDH in the children with BA depending on the level of its control, it was found to be increased twofold in the children with UC BA compared to those of the control group and $C B A(P<0.001)$, and by 1.8 times compared to those with $\mathrm{PC} B A(P<0.05)$ (Fig. 2).

\section{Discussion}

When uncontrolled, asthma can limit the daily activities and is sometimes fatal. Acute severe asthma represents progressive airway narrowing to the extent where the patient is distressed at rest and may have signs of cardiac stress. Bronchial asthma independently increases the risk of developing cardiovascular disease [8]. There are limited data on electrolyte disturbances in acute asthma. The present study was designed to investigate specific features of potassium metabolism and myocardial damage markers in the children with bronchial asthma, depending on the level of BA control. We know that, potassium is the second most abundant cation in the body and electrolyte levels directly influence excitability of airway smooth muscles (ASM) by influencing the state of ion exchangers and $\mathrm{Na}^{+} / \mathrm{K}^{+}$pump. Possible hypotheses

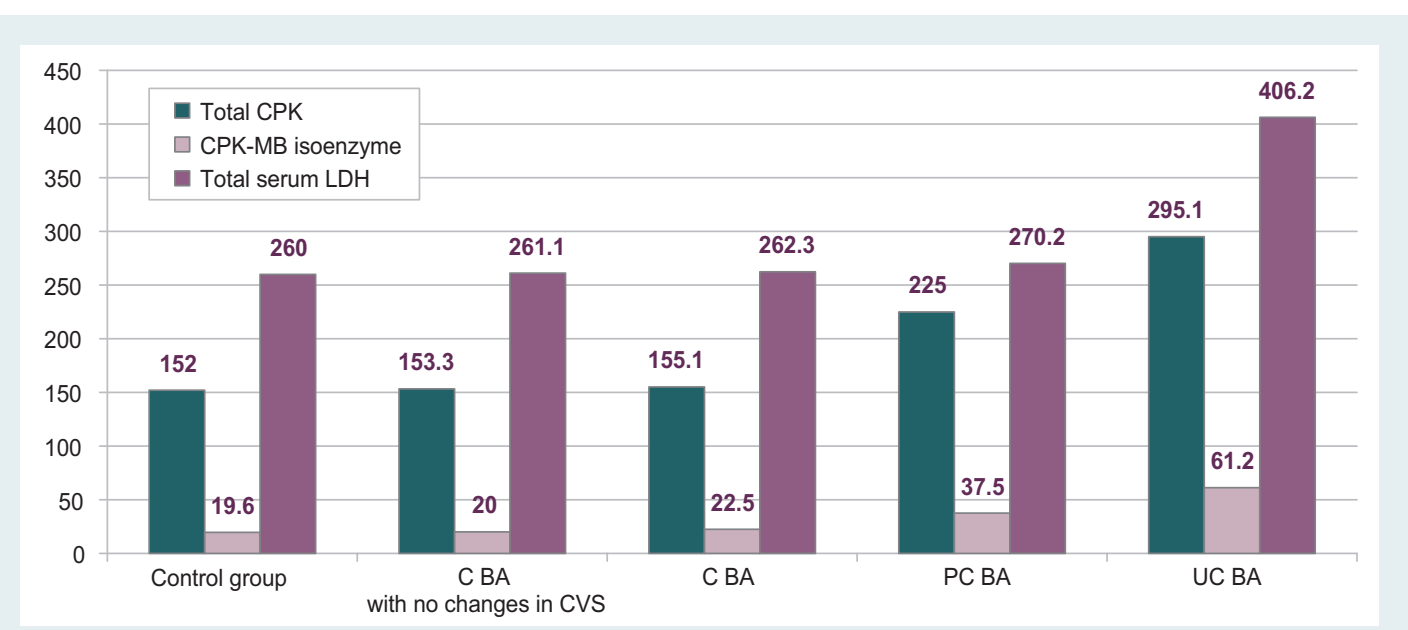

Fig. 2. The level of general CPK, CPK-MB isoenzyme and total serum LDH in children at different levels of control of bronchial asthma, (U/I). 
that may lead to airway reactivity include a direct effect of electrolytes on bronchial smooth muscle contractility as well as potential enhancement of the release of mast cell-derived inflammatory mediators, possibly through airway osmolarity changes [9].

On the other hand, we noticed that more patients with acute asthma exacerbation had hypokalemia and there was a significant decrease in potassium level. In our study, proportions were for potassium, in the children with UC BA serum $\mathrm{K}^{+}$level was found to be 3.2 [3.0-4.0] $\mathrm{mmol} / \mathrm{l}$, being significantly lower compared to the children with $\mathrm{PC} \mathrm{BA} \mathrm{-} 3.7$ [3.2-4.2] mmol// л $(\mathrm{P}<0.01), \mathrm{C} \mathrm{BA}-4.2$ [3.8-4.5] mmol// $(P<0.001)$, this is in agreement with the study by P. Ravikumar et al., who also noticed that the lowest proportions for potassium serum levels were $3.30 \pm 0.01 \mathrm{mmol} / / \mathrm{l}[8]$.

Treatment of acute asthma consists of repeated doses of nebulized $\beta_{2}$-agonists, systemic steroids and aminophylline in unresponsive cases. The administration of salbutamol during the emergency treatment of acute severe asthma was shown to be associated with a significant decrease in serum magnesium, potassium and phosphate levels [12].

Results similar to our results were obtained by S. N. Karmali et al. [13], who concluded that a single dose of $\beta_{2}$-agonist increased the heart rate by 9.12 beats $/ \mathrm{min}$ and reduced the potassium concentration by $0.36 \mathrm{mmol} / \mathrm{L}$, compared to placebo. For trials lasting from 3 days to 1 year, $\beta_{2}$-agonist treatment significantly increased the risk for a cardiovascular event (relative risk [RR], 2.54; $95 \% \mathrm{Cl}$, 1.59 to 4.05 ) compared to placebo. The RR for sinus tachycardia alone was 3.06 and for all other events it was 1.66.

Present study is consistent with study done by A. M. Hala et al. [10] that the therapeutic drugs administered for the management of asthma were found to have an effect on the serum potassium levels. Hypokalemia were more prevalent among asthmatics that received $\beta 2$-agonist in either monotherapy or combined with steroid and or theophylline, whereas A. Lorensia et al. [11] found that there is no significant difference in sodium $(P>0.866)$ and potassium $(P>0.470)$ level in blood as a response to the asthma exacerbations treatment by intravenous aminophylline compared to nebulized salbutamol. Although there was no significant difference in the incidence of electrolyte disturbances in both drugs, but close monitoring is still needed to prevent any side effects incident.

The study by V. Arunachalam et al. [9] revealed the decrease in serum potassium level is high in children who received more than three doses of salbutamol.

Recently, the results of N. Shaikh et al. [14] study indicated that serum electrolytes like magnesium, potassium and phosphate decreased significantly in patients with acute severe asthma who were on treatment with nebulized salbutamol. The mechanism and clinical significance of these findings are unclear and they require further studies.

Salbutamol is an adrenergic agonist which principle effect is stimulation of $\beta 2$-receptors with resultant bronchodilation. Compared with oral or parenteral routes of administration, inhalation of salbutamol has reportedly been associated with fewer systemic side-effects for equivalent bronchodilator effect [15].
Nevertheless, there is evidence of systemic absorption of the inhaled drug, which may result in clinical significance. As inhaled $\beta_{2}$-agonists have systemic cardiovascular effects, and elevations in arterial stiffness and sympathetic nerve activity are associated with increased cardiovascular morbidity/mortality [16].

Our study found that the children with UC BA, hypokalihistia, and combined hypokalemia and hypokalihistia had prolonged QT interval more often, indicating an increased risk of fatal arrhythmias and sudden death syndrome that this is in agreement with the study by H. Edgell et al. [15], who also noticed that the hypokalemia, hypomagnesemia, and hypocalcemia are well-known causes of cardiac arrhythmia. In another study, it was found that sodium, potassium and magnesium concentrations of asthmatic patients showed no significant differences in the means when compared with the control group, but elevated levels of sodium were associated with poor ventilatory function. High levels of potassium were associated with better pulmonary ventilation [17].

The influence of pathogenic factors in bronchial asthma leads to violations of metabolic processes in the myocardium. The earliest manifestations of significant metabolic and morphological changes in the myocardium in BA are the increase in the content of myocardial damage markers in the blood [18].

According to the study by F. Healy et al. [19] an increase in the level of cardiospecific enzymes is observed for 2-3 weeks previously observed on ECG signs of violation of repolarization and depolarization, which can serve as a diagnostic and prognostic criterion of severity of asthma, as well as adequacy of medical therapy as the main disease and detected violations of the cardiovascular system.

In the study, V. Umalakshmi and K. Bhargavi [20] established a significant increase of creatine kinase $(P<0.01)$, lactate dehydrogenase $(P<0.01)$ and lipid profile $(P<0.01)$ in exacerbation of asthma when compared to controls. No statistical significance was observed in stable asthma when compared to controls. Creatine kinase and lactate dehydrogenase levels increased significantly and lipid profile showed a decrease in exacerbating asthma when compared to stable asthma patients. To correlate these levels and predict the risk of severity of asthma and help the clinician in diagnosis and implementation of appropriate treatment and prevent the risk of fatal asthma.

What coincides with the data obtained by us? In our study it is established that in children with uncontrolled asthma decrease of the level of potassium in the blood serum and in red blood cells, increase of the level of total creatine phosphokinase and isoenzymes of LDH-1 by two times, isoenzyme creatine phosphokinase-MB fraction by three times and increase of the total lactate dehydrogenase by 1.5 times were marked more significantly.

\section{Conclusion}

Thus, the study demonstrated significant decrease of potassium level in blood serum and erythrocytes, increase of total creatine phosphokinase and lactic dehydrogenase-1 isoenzyme levels, increase in creatine phosphokinase-MB 
isoenzyme level, and one and a half time increase of total lactic dehydrogenase in the children with uncontrolled course of bronchial asthma. The major reasons of decreased potassium level in blood serum and erythrocytes are misuse of short-acting beta-2 agonists, prolonged course of the disease, and noncompliance of basic therapy.

Directions for future research. The results of the study have led to the conclusion that the children with uncontrolled bronchial asthma require correction of metabolic disturbances of myocardium. Because of that, further investigations should involve the assessment of basic therapy efficiency in combination with cardioprotective drugs.

Conflicts of interest: authors have no conflict of interest to declare. Конфлікт інтересів: віАсутній.

Information about authors:

Herasymova 0. V., MD, PhD, Assistant of the Department of Pediatrics № 1, National Pirogov Memorial Medical University, Vinnytsia, Ukraine.

Protsiuk T. L., MD, PhD, DSc, Associate Professor of the Department of Pediatrics № 1, National Pirogov Memorial Medical University, Vinnytsia, Ukraine.

Protsiuk L. O., MD, PhD, Assistant of the Department of Hygiene and Ecology, National Pirogov Memorial Medical University, Vinnytsia, Ukraine.

Dudarenko O.B., MD, PhD, DSc, Associate Professor of the Department of Hygiene and Ecology, National Pirogov Memorial Medical University, Vinnytsia, Ukraine. Kuleshov 0. V., MD, PhD, DSc, Associate Professor of the Department of Propedeutics of Pediatric Diseases with Patient Care, National Pirogov Memorial Medical University, Vinnytsia, Ukraine.

\section{Відомості про авторів:}

Герасимова О. В., канА. меА. наук, асистент каф. педіатрії № 1 , Вінницький національний меАичний університет імені М. І. Пирогова, Україна.

Процюк Т. ^., А-р меА. наук, Аоцент каф. пеАіатрії № 1, Вінницький національний меАичний університет імені М. І. Пирогова, Україна.

Процюк $\Lambda$. О., канд. меА. наук, асистент каф. загальної гігієни та екології, Вінницький національний меАичний університет імені М. І. Пирогова, Україна.

Аударенко О. Б., канА. меА. наук, доцент каф. загальної гігієни та екології, Вінницький національний медичний університет імені М. І. Пирогова, Україна.

Кулешов О. В., канА. меА. наук, доцент каф. пропеАевтики Аитячих захворювань та Аогляду за хворими Аітьми, Вінницький національний медичний університет імені М. І. Пирогова, Україна.

\section{Сведения об авторах:}

Герасимова Е. В., канА. меА. наук, ассистент каф. педиатрии № 1, Винницкий национальный медицинский университет имени Н. И. Пирогова, Украина.

Процюк Т. ^., А-р меА. наук, Аоцент каф. пеАиатрии № 1 Винницкий национальный меАицинский университет имени Н. И. Пирогова, Украина.

Процюк $\Lambda$. А., канА. меА. наук, ассистент каф. общей гигиены и экологии, Винницкий национальный медицинский университет имени Н. И. Пирогова, Украина. Аударенко О. Б., канА. меА. наук, Аоцент каф. общей гигиены и экологии, Винницкий национальный меАицинский университет имени Н. И. Пирогова, Украина. Кулешов О. В., канА. меА. наук, Аоцент каф. пропеАевтики Аетских болезней и ухода за больными Аетьми, Винницкий национальный медицинский университет имени Н. И. Пирогова, Украина.
НаАійшла Ао редакції / Received: 02.07.2018

Після Аоопрацювання / Revised: 27.09.2018

Прийнято Ао Аруку / Accepted: 03.10.2018

\section{References}

[1] Schatz, M., \& Rosenwasser, L. J. (2014) The allergic asthma phenotype. Allergy Clin Immunol Pract., 2(6), 645-8. doi: 10.1016/j. jaip.2014.09.004.

[2] Farzan, S. (2013) The asthma phenotype in the obese: distinct or otherwise? J Allergy (Cairo), 2013. doi: 10.1155/2013/602908.

[3] Rowan, S. C, Keane, M. P., Gaine S., \& McLoughlin P. (2016) Hypoxic pulmonary hypertension in chronic lung diseases: novel vasoconstrictor pathways. Lancet Respir Med., 4(3), 225-36. doi: 10.1016/S22132600(15)00517-2.

[4] Paulin, R., \& Michelakis, E. D. (2014) The metabolic theory of pulmonary arterial hypertension. Circ Res., 115(1), 148-164. doi: 10.1161/ CIRCRESAHA.115.301130.

[5] Umalakshmi, V. \& Bhargavi, K. (2015). Serum creatine kinase, lactate dehydrogenase and lipid profile in patients with asthma. Journal of Pharmacy and Biological Sciences, 10(3), 53-56. doi: 10.9790/300810335356.

[6] Faruqi, R., Wilmot, C., Wright, A. H., \& Morice, A. H. (2012) Serum LDH in chronic cough: a potential marker of airway inflammationcrj. The Clinical Respiratory Journal, 6(2), 81-87. doi: 10.1111/j.1752699X.2011.00250.X.

[7] Sahan, M., Yılmaz, M., Gokel, Y., Erden, E. S., \& Karakus, A. (2013) Nebulized salbutamol for asthma: effects on serum potassium and phosphate levels at the $60 \mathrm{~min}$. Rev. Port Pneumol, 19(5), 200-203. doi: 10.1016/j.rppneu.2012.12.003

[8] Ravikumar, P., Priyadarshini Bai, G., \& Suryanarayana, H .V. (2013) Study of electro-lyte disturbances in acute asthma. Int J Biol Med Res., 4(3), 3479-3482.

[9] Arunachalam, V., Venkatasubramanian, R., Heber, A., \& Padmanabhan, R. (2016). Effect of salbutamol nebulization in serum potassium level in pediatric acute bronchial asthma. International journal of scientific research, 5(9), 198-204.

[10] Mohammad, H. A., Abdulfttah, M. T., Abdulazez, A. O., Mahmoud, A. M., \& Rasha, M. A. (2014). Study of electrolyte disturbances in patients with chronic stable asthma and with asthma attacks. Egyptian Journal of Chest Diseases and Tuberculosis,63(3), 529-534. doi: https://doi. org/10.1016/j.ejcdt.2014.03.010.

[11] Lorensia, A., Ikawati, Z., Andayani, T., Maranatha, D., \& Wahjudi, M. (2016) Comparison of Electrolyte Disturbance of Using Intravenous Aminophylline Versus Nebulization Salbutamol for Exacerbation Asthma in Surabaya, Indonesia. International Journal of Pharmaceutical and Clinical Research, 8(4), 221-228.

[12] Andrzejowski, P., \& Carroll, W. (2016) Salbutamol in paediatrics: pharmacology, prescribing and controversies. Arch Dis Child Educ Pract Ed., 101(4), 194-7. doi: 10.1136/archdischild-2014-307285

[13] Karmali, S. N., Sciusco, A., May, S. M., \& Ackland, L. G. (2017) Heart rate variability in critical care medicine: a systematic review. Intensive Care Med Exp., 5(1), 33. doi: 10.1186/s40635-017-0146-1.

[14] Shaikh, N., Reddy, Br., Gokani, R., \& Patel, Bh. (2015). Prevalence of electrolyte disturbances in acute exacerbation of bronchial asthma. EJPMR., 2(5), 562-568.

[15] Rachaiah, J., \& Rachaiah, N. (2013) Unusual cause of hypokalemia and paralysis in an elderly patient with Bronchial Asthma. International Journal of Medical Science and Public Health., 2(4), 1114-1116. doi: 10.5455/ijmsph.2013.030720132.

[16] Edgell, H., Moore, L. E., Chung, C, Byers, B. W., \& Stickland M. K. (2016). Short-term cardiovascular and autonomic effects of inhaled salbutamol. Respir Physiol Neurobiol., 231, 14-20. doi: 10.1016/j. resp.2016.05.014

[17] Lutfi, M. F. (2013) Electrolytes levels in asthmatic patients. Asian Journal of Biomedical and Pharmaceutical Sciences, 3(19), 1-4.

[18] Oliveira, N. S., Silva, V. R., Castelo, J. S., Elias-Neto, J., Pereira, F. E., \& Carvalho, W. B.. (2008) Serum level of cardiac troponin I in pediatric patients with sepsis or septic shock. Pediatr. Crit. Care. Med., 9(4), 414-417. doi: 10.1097/PCC.0b013e31817e2b33.

[19] Healy, F., Hanna, B. D., \& Zinman, R. (2010) Clinical practice. The impact of lung disease on the heart and cardiac disease on the lungs. Eur. J. Pediatr., 169(1), 1-6. doi: 10.1007/s00431-009-1027-8.

[20] Umalakshmi, V., \& Bhargavi, K. (2015) Serum creatine kinase, lactate dehydrogenase and lipid profile in patients with asthma. Journal of Pharmacy and Biological Sciences, 10(3), 53-56. doi: 10.9790/300810335356. 